DOI https://doi.org/10.30525/978-9934-26-109-1-27

\title{
РОЗРОБКА МОБІЛЬНОГО КОМПЛЕКСУ \\ ДЛЯ ДІАГНОСТИКИ ЕКСПЛУАТАЦІЙНОГО СТАНУ ДОРОЖНІХ ПОКРИТТІВ «МК-ДЕС-НТУ»
}

\author{
Шуляк I. C. \\ кандидат технічних наук, \\ доцент кафедри проектування доріг, геодезії та землеустрою \\ Національний транспортний університет
}

\section{Чечуга О. С.}

кандидат технічних наук, доцент,

доиент кафедри транспортного будівництва та управління майном Національний транспортний університет

\section{м. Київ, Украӥна}

В лабораторії автомобільних доріг та аеродромів Національного транспортного університету розроблено експериментальний зразок мобільного комплексу для діагностики експлуатаційного стану дорожніх покриттів «МК-ДЕС-НТУ», що містить вузол вимірювання коефіцієнта зчеплення, вузол вимірювання рівності покриття, вузол вимірювання прогину дорожнього одягу, одометр, вимірювач швидкості руху, обладнаний новітніми цифровими датчиками цифровими акселерометрами та високоточними енкодерами, та дає можливість удосконалити процес визначення параметрів дорожніх покриттів, підвищити точність результатів вимірювань, підвищити безпеку виконання вимірювань, зменшити трудомісткість вимірювальних процесів, підвищити конкурентоздатність вимірювального обладнання (рис. 1).

Розроблено програмне забезпечення для керування процесами вимірювання, обробки і реєстрації даних, а також керування силовими органами та органами контролю виконання. Розроблено програмне забезпечення системи прийому та первинної обробки сигналів 3 датчиків.

Особливістю розробленого комплексу $є$ те, що він дає змогу вимірювати модуль деформації, а не прийнятий у теперішній час в нормативних документах України та СНД модуль пружності $[1$, с. 6], який не відображає дійсного експлуатаційного стану автомобільних 
доріг. Це уможливлює суттєвий прорив в галузі будівництва доріг, наближення критеріїв їх міцності до тих, які використовуються за кордоном, зокрема, в Німеччині, Австрії, Швейцарії [2, с. 5; 3, с. 11; 4, с. 9].

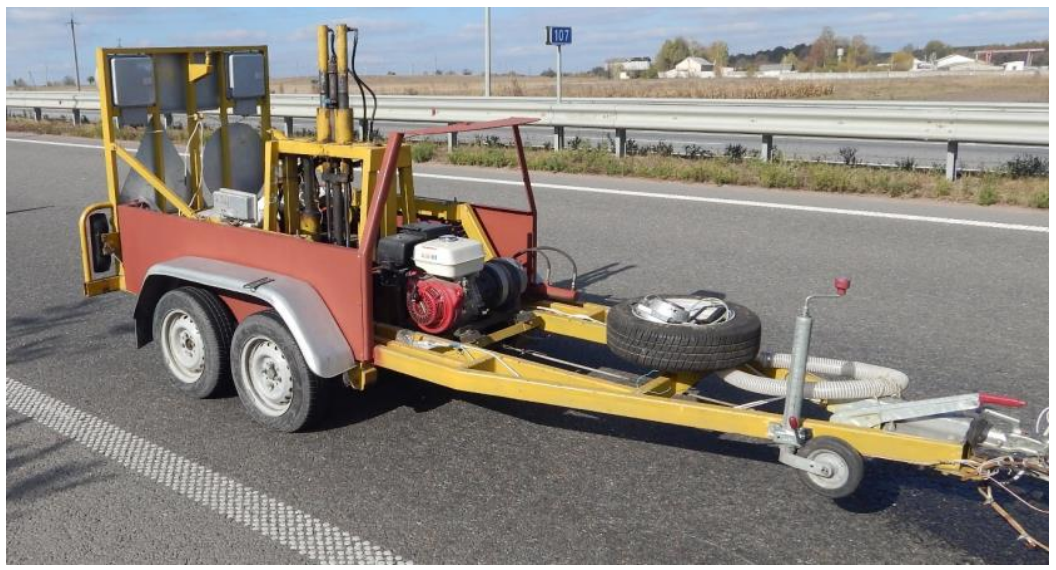

\section{Рис. 1. Мобільний комплекс «МК-ДЕС-НТУ»}

Схеми нового обладнання були запроектовані та розроблені на основі дослідження та аналізу фізичних явищ та процесів, які мають місце при взаємодії транспортних засобів $з$ дорогою. Експлуатаційна надійність обладнання доведена в процесі експериментальних випробувань на дослідних ділянках автомобільних доріг м. Києва, Київської, Житомирської, Рівненської областей.

«МК-ДЕС-НТУ» перевершує існуючі установки для визначення експлуатаційного стану дорожніх покриттів за рахунок нового підходу у конструюванні - розміщення вузлів для вимірювання різних показників якості на одному шасі. Також розроблений мобільний комплекс є значно дешевшим за відомі зарубіжні аналоги.

Розробка даного типу вимірювального обладнання сприяе розв'язанню питання удосконалення системи оцінки транспортноексплуатаційних показників дорожніх конструкцій, яке $є$ надзвичайно важливим в дорожній галузі. Точність та об'єктивність оцінки експлуатаційного стану дорожніх покриттів дає можливість своєчасно виявляти ділянки доріг з недостатніми транспортно-експлуатаційними показниками та проводити заходи щодо їх посилення, що сприяє покращенню транспортно-експлуатаційного стану автомобільних доріг. 


\section{Література:}

1. ДСТУ Б В.2.3-42:2016. Автомобільні дороги. Методи визначення деформаційних характеристик земляного полотна та дорожнього одягу. [Чинний від 2017-04-01]. Вид. офіц. Київ : Мінрегіон України, 2016. 47 c.

2. DIN 18134 (1990): Baugrund. Versuche und Versuchsgeräte. Platten-druckversuch. Deutsches Institut für Normund.

3. Richtlinien und Vorschriften für den Straßenbau RVS 8S.02.6: Erdarbeiten. Kontinuierlicher walzenintegrierter Verdichtungsnachweis. Forschungsgesellschaft für das Straßenwesen im ÖIAV, Wien. 1999. 34 p.

4. SVN 670317: Versuche. Plattenversuch. Vereinigung Schweizeri`scher Straßenfachmänner (VSS), Zürich. 1999. 32 p. 